\title{
CULTURAL CAPITAL AND THE TALE OF TWO LU XUNS
}

\author{
Yang Ke \\ Central China Normal University \\ keyang2001@yahoo.com / keyang@umass.edu
}

\begin{abstract}
Historically, Lu Xun's canonical status in China had been used for purposes other than strictly or specifically "literary," although the aesthetic merits of his works remain indisputable even from the broader perspective of World Literature today. Nonetheless, such uses, which this study refers to as "cultural capital," have brought about certain inconsistencies and contradictions in the evaluation of his works. In order to survey the complex and shifting history of reception to Lu Xun's works, this paper attempts to explain the contextual determinations of his canonicity from the rise of vernacular literature in 1917 in China and his use of sophisticated techniques of the short story from the modern aesthetics learned when he studied abroad. Both developments earned Lu Xun a fairly wide readership among the Chinese, and the respect of Chinese intellectuals and the literati from the very beginning of his career; later, his essays on revolutionary literature and proletarian literature appear to have contributed to his full recognition even by the Communist Party since the 1930s. The positive reception of these different sectors resulted in a "cultural capital" that would be at the core of the changes in the history of the reception to his works in China. Drawing from Pierre Bourdieu's theorization and John Guillory's elaboration in terms of literary evaluation and in order to show how Lu Xun's works were used as cultural capital, this paper discusses the changes in representation of Lu Xun's works in Middle School and High School Chinese textbooks, as well as the related historical movements and social activities after the founding of the People's Republic of China. The discussion also tries to show how he was later aligned with the political struggle and propaganda demands to convince the masses to follow the government's policy and practice. In this regard, the study attempts to describe how his works were chosen in accordance with the mechanisms by which political preferences and cultural values are historically inculcated and normalized in literature in China. All these developments resulted in the production of "Lu Xun" whose hybrid identity was anchored on the differing and contradictory uses as cultural capital.
\end{abstract}




\section{Keywords}

cultural capital, literary canon, Lu Xun, uses of Lu Xun's works

\section{About the Author}

Yang Ke is a lecturer of English at Central China Normal University. She received her PhD degree in English Language and Literature in 2015 from the English Department, Ateneo de Manila University. Her academic research focuses on world literature, world Englishes, and Lu Xun Studies. She has published many papers in journals and delivered lectures at international conferences. 


\section{INTRODUCTION}

Issues about the concept of the literary canon and canon formation have long been the subject of public controversy in relation to the cultural content of higher education. In the 1980s, in particular, the debates about which texts students should study at school in the United States and elsewhere in the world became the center of heated controversy among scholars, teachers, and the public. Generally, the arguments seemed to have simply boiled down to the division between those who upheld the traditional canon and those who were critical of it.

But the criticism, of course, was less flat and simple than just a mere polarization between pro-and-anti positions. The critical and literary theories behind the "canon wars" underscored the apparent exclusions by the traditional canon - exclusions involving multiple concerns like race, class, ethnicity, gender and sexuality, in particular. Thus, critics called for the canon to be broadened and to become more inclusive rather than remain narrow and exclusive (Greenbaum 36).

The theoretical underpinning of the debate, therefore, is the issue of representation of authors / texts around any or all of the multiple concerns which may boil down to the following questions: (1) Whose/which texts are represented in the literary canon? (2) Which author/text comes in or goes out of the canon and why? These are a couple of the many complicated questions surrounding the debates about the canon and the attempts at reforms that followed. Thus, Benton has referred to the "canon wars" which raged in higher education in the West as a matter of a division between "those who supported a unitary canon and their challengers advocating pluralism" (269).

John Guillory states that “[a]n individual's judgment that a work is great does nothing in itself to preserve that work, unless that judgment is made in a certain institutional context, a setting in which it is possible to insure the reproduction of the work, its continual reintroduction to generations of readers" (237). Thus, it may be said that the traditional canon has been constituted, affirmed and revised within institutional settings rather than through the personal will of individual influential critics alone. It is within these institutions that texts are valued and evaluated (as well as reproduced, circulated and disseminated) according to a diverse and complex range of social circumstances and historical determinations.

Specifically, however, Hunter emphasizes that "one of the battlegrounds on which the culture wars have been fought most vigorously in recent years is in education, and in particular, the curriculum" (173-174). Understandably, books and ideas are selected, read, and taught in academic institutions, and in effect, they become important sites for canon formation. For example, implied in the 
curriculum design is the value judgment concerning what texts and authors to use for classroom lessons. Decisions concerning whether or not to teach the classics or contemporary texts, whether or not the texts represented are sufficiently varied, or whether or not the decision for selection of authors/texts is arbitrary or based on a clearly articulated principle of representation, are among a number of considerations potentially used as the basis for selection or inclusion. Therefore, the importance of the canon wars cannot be underestimated especially in the context of educational institutions today in which the canon is centrally constituted, affirmed, circulated, reproduced and revised in the curriculum.

Since the 1980s, scholars and critics worldwide have undertaken critical approaches to literary studies that focus on canon-related issues with great urgency and importance. "This, to the extent that, as Gilbert and Gubar assert, "these [canon] wars were impinging on our lives as writers, readers, and teachers, no matter how we tried to ignore them" (xii). It is in the context of those debates that the canon, conventionally believed to be a stable list of great works in the long view of a nation's literary history, has been observed to be a fairly unstable affair and subject to changes in unexpected ways; as such, canon formation (i.e. the process of establishing the canon) is highly complex.

From this perspective, this study focuses on the canon-related issues as illustrated by the case of the inclusion / exclusion of Lu Xun's works in the Middle and High School Chinese textbooks in order to investigate the process of canon formation.

In China, among the hallmarks of the modern Chinese literary canon is Lu Xun. In the 1980 , in the context of the external and internal dynamics of globalization and changes in local state policies, educational reforms were launched which may have led to changes in Lu Xun's place in the Middle School and High School Chinese textbooks.

In general, as the "father of Chinese modern literature," Lu Xun enjoys a high reputation in China and academic studies on him and his works have been documented in articles, lectures, and so on, both in life and death. More significantly, his works have been included in the Middle School and High School Chinese textbooks and read as canonical works since the 1920 .

However, certain changes began to be observed when China entered the 21st century. Academic studies on Lu Xun continued to flourish, generally, apparently affirming his canonicity; yet, some of his works with historically long-standing canonical status in Chinese textbooks began to be replaced in the Middle School and High School Chinese curriculum. 
In light of the worldwide debates on the traditional canon, this study has observed changes in the representation of Lu Xun's works in the Middle School and High School Chinese textbooks since the 1920s. This is suggestive of the complex process of canon formation as illustrated by the way Lu Xun's works have been actually represented in the Chinese textbooks, historically. As a corollary, this study also hopes to affirm that the canon is indeed an unstable affair in quite distinct and specific ways as illustrated by the changes in the reception of Lu Xun's works in China. Therefore, this study traces the development of these changes in relation to the concrete conditions of Chinese society and history.

From this perspective, the study points to instabilities in Lu Xun's canonization in China in relation to the changes in the formation and reformation of the Chinese canon. Specifically, this study tries to address the issues of how Lu Xun's works were selected, why they were selected and why certain works seem to be "disappearing" from the educational curriculum.

Pierre Bourdieu states in The Field of Cultural Production: Essays on Arts and Literature that the literary field is "a field of forces, but it is also a field of struggles tending to transform or conserve this field of forces" (30). Thus it is clear that the position and the status of cultural productions are the result of the competition (actively or passively) for authority among power relations. In relation to the formation of the canon, the operation of state power that plays an important role in the construction of the literary canon is quite a complicated process which represents diverse features and forces in different times. In general, this process involves the choice of the preferred literary works, and the strategy of bringing them into the national educational system. The process of canonization of literary works essentially consists of these two steps.

Take the famous Dream of the Red Chamber (the translation by David Hawkes, The Story of the Stone, seems appropriate, because it is closer to the Cao Xueqin's original title for the book. Here, however, Dream of the Red Chamber is used due to its familiarity to the public) and Outlaws of the Marsh as examples which have been indisputable parts of the Chinese literary canon in modern times, but which was not the case in the past. The reality is they had been officially banned books even during the Qing dynasty (1644-1912) and were not accepted by orthodox Chinese intellectuals for the so-called alleged salacious descriptions and the rebellious spirit.

It was not until the end of the Qing Dynasty that the status of those traditional classical Chinese literatures were changed. Confronted by the needs of the national revolution and national liberation, the revaluation movement of classical Chinese novels like Dream of the Red Chamber and Outlaws of the Marsh was initiated by the progressive intellectuals in order to awaken the masses from the restrictions 
of Confucianism. Later, the movement was expanded by renowned scholars like $\mathrm{Hu}$ Shi and $\mathrm{Lu}$ Xun in the 1920s, and finally the traditional vernacular novels were introduced into the modern university research and educational system and were regarded as important components of the new national literature. The existence of numerous research institutions and university secondary disciplines under Modern Chinese Literature, which focus on the study of classical Chinese literature like Dream of the Red Chamber and Outlaws of the Marsh, in China today illustrates the influence of the movement, but it was their accreditation by the modern educational system that enabled them to be part of the literary canon (Liu XiangAn 22). This is not to deny their inherent literary greatness but only to emphasize the important role the educational institutions played in the process of canon formation.

Elite intellectuals seemingly played a decisive role in the canon formation process, but it may also be said that they just adapted to the historical requirements of the nation's dominant power's discourse construction even as they might have historically intervened in undertaking changes in the canon as may be gleaned from the preceding discussion. It was mainly through the operation of state power that canon formation took place as canonical texts embody a kind of symbolic capital that was made to be an organic part of the national mainstream discourse. In practice, it was through the educational system that the literary canon gained influence and provided access to the common public. Therefore, the establishment of the literary canon, in the case of Lu Xun, specifically, is closely linked with the mainstream power discourse and the country's educational institutions.

It is natural and inevitable that the nation's mainstream discourse should require the educational system to keep in pace with its ideological "preference." But it might be said that there are differences between literary canon education, which embodies the national mainstream discourse, and literary education. The literary canon education's main purpose lies in its didactic function which is to rally readers strictly around "values" represented by a nation's canonical authors, and to encourage people to serve the country. But literary education focuses on humanism and the individual's development; its concern is with the aesthetic and humanistic qualities of literary works and not simply with state ideology, history, or cultural symptom. While cognizant of contextual considerations, literary education is concerned with the mutually constitutive relationship between text and context.

In relation to the changes of Lu Xun's works in the Middle School and High School Chinese textbooks from the 1920s until 2013, it has become apparent that the function of national mainstream discourse has overweighed its function to provide literary education. The inclusion and teaching of Lu Xun's works in Middle School and High School Chinese subject attests to the priority of ideological 
considerations, although there is no question about his greatness as an author and the great aesthetic value of his works. This is not merely to comment on the power play of the mainstream discourse in literary education, but rather to draw attention to how the canon has been established in consideration of its historical context, seeing Lu Xun's ups-and-downs in relation to the interest of the state and the power relations which are at play.

In the following section, the consequent changes of Lu Xun's works in Middle School and High School Chinese textbooks in accordance with the historical movements and social developments will be discussed to see how Lu Xun's canonical status was established by the uses of his works. What it hopes to argue is that his uses constituted his canonicity.

\section{THE RISE OF VERNACULAR LITERATURE IN 1917}

In today's society, nobody can escape the social, cultural, political, and economic influences of the outside world. Texts have a "subtext" consisting of the economic, political, and social aspects of society and history. Frederic Jameson states that the subtext is not only a passive ground which the text reflects as a series of determinate contradictions but also buried deep down in the psyche as a "political unconscious" (20). "Everything is 'in the last analysis' political" (Jameson 20). From this perspective, the paper launches its critical application of Barbara Herrnstein Smith's theory on "Value/Evaluation" and Jameson's theory.

Nothing in the world can be completely separated from the other; an entire society is made up of parts which are intricately interwoven, critics and texts belong to this "world." Thus, "literature should be read in relation to culture, history, society, and other factors that help determine a text's meaning" (Bressler 215). Stephen Greenblatt states that history and literature must be seen as disciplines that should be analyzed together. He argues that those important components of the world, people, reality, history are inter-subjective, and overdetermined. So scholars contend that a text does not exist as a separate entity, but is tied to culture and society. In addition, it is necessary to examine the social sphere in which the author lived, the psychological background of the author, the books and theories that may have influenced the author, and any other possible factors which are related to the work. Take a look at the historical background of Lu Xun's works, for example. Knowledge of Lu Xun's society could help the readers understand why Julia Lovell, a translator of Lu Xun's work, says, "to read Lu Xun is to capture a snapshot of late imperial and early Republican China." 
The context of the world he lived in was the 19th century, a "crazy" age in which Chinese cultural values began to be questioned, re-examined, and even criticized. At the same time, Western models were being introduced to fill in the vacuum in many cultural practices. The Chinese intellectuals began to reflect upon what could be the reason for the failure of Chinese culture and began to undertake some changes.

According to theories of modern linguistics, language is not only a tool or a medium, but also a basic structure, which is able to organize new words even as it shapes modes of thinking. In fact, the first reform in China happened in the realm of language. Chinese writers and scholars were under the double, even triple, pressures from the Chinese society: the reality of poverty in their motherland, the eagerness to change the country's fate, and the impact of western science and ideas. Under such tremendous pressures, Chinese traditional culture suffered from an internal collapse. In the midst of such collapse, the language of writing changed from the classical Chinese [文言wenyan] to the daily spoken (vernacular) language [白话baihua].

The declaration of Hu Shi (1891-1962), “Don't hesitate to use colloquial words and expressions," in his article "Suggestions for a Reform of Literature" published in the New Youth in January 1917 ignited the literary movement in Chinese literary history. In an article in New Youth, Chen Duxiu appealed for the new, plain, and popular literature to be written in China to replace the "ornate, adulatory literature of the aristocracy," "stale, bombastic literature of classicism," and "obscure, difficult literature of the hermit and the recluse" (qtd. in Hsia, A History 4). For them, baihua (vernacular) and vernacular literature could convey new ideas, new social orders, and present the new changing social realities among the people.

Almost overnight, Chinese writers and scholars cut themselves off from their classical tradition and involved themselves in the political world. On the one hand, Chinese literature had to perform its role in advocating the unity of the whole nation's consciousness with dignity in the face of the national crisis caused by foreign countries' invasion; on the other hand, Chinese writers and scholars had to think about how to locate Chinese literature at that disturbing time. The theme of crisis became a common topic during the process of coping with the external political environment and the Chinese writers' and scholars' own adaptation to the crisis. Under such great pressure, one who had the courage to stand up and face up to the crisis might as well be considered the spiritual warrior of the Chinese people. This is why even at the beginning of his writing career, Lu Xun had already been declared a national hero and was later worshipped by generations. 
The political revolution was followed by a literary revolution; thus, the May Fourth Movement also marked the beginning of the New Cultural Movement. The Chinese intellectuals pondered on what reforms would be helpful to save the Chinese nation from dissolution. After locating the problem in the spirit of the people, they tried to find a way to reinvigorate it. According to Xu Shoushan's recollections, when Lu Xun was in Japan, he used to discuss three interrelated questions with his friend: "What is the ideal nature of man?", "What is lacking in the Chinese national character?", and "What is the root of China's illness?" (Xu Shoushan, qtd. in Leo Ou-fan 174). Driven by the intention to inject the Chinese people with a new spirit, Lu Xun began to write his short stories. As mentioned in the preface to Nahan in 1923, Lu Xun states, "the most important thing, therefore, was to change [the Chinese] spirit, and since at that time I felt that literature was the best means to this end, I determined to promote a literary movement" (qtd. in Yang Hsien-yi and Gladys Yang 76).

It is noteworthy to say that for one intellectual to make up one's mind to pursue the profession as a novelist in the 190os, the commitment must have been exceptionally strong. Although the vernacular Chinese fictions had come into being since the Song Dynasty (960-1279) in the form of the script for story-telling, even before Hu Shi's call for the vernacular literature, there were novels like The Travels of Lao T'an and Bureaucracy Exposed which had been written in vernacular Chinese already in the Late Qing Dynasty. However, the novel and the writer could not acquire nationwide recognition due to the fact that the novel was not accepted as legitimate knowledge or a valid learning material by the literati and officialdom who had been trained or forced by the Imperial Examination system to focus only on Confucian classics (Li Lianjun 86). Novelists did not have the social position or literary reputation that they deserved, nor did they have the qualification to let them stand alongside poets. Novels were regarded only as entertainment in Confucian educational system and enjoyed its popularity among the illiterate public, who were looked down upon by the upper class or social elite (Li Lianjun 87).

Ironically, it was the widespread recognition of the novel among the public that made the progressive intellectuals see in it the opportunity to express their revolutionary ideas. The extensive readership of New Youth and Dongfang Zazhi attracted scholars' interest to "recreate" the novel in order to adapt to the new demands of the country's development. Thus the "revolution in fiction" was proposed by Liang Qichao and developed the slogan, “To rejuvenate a nation's citizens, a nation's fiction must be first rejuvenated" (36). Against this backdrop, the significance of Lu Xun's “A Madman's Diary" (1918) was noteworthy. It is a story about a paranoiac who thinks everyone around him is a cannibal; he wonders 
who the "real man" is and who the "primitive people" are. The madman says to his brother,

Brother, probably all primitive people ate a little human flesh to begin with. Later, because their outlook changed, some of them stopped, and because they tried to be good, they changed into men, changed into real men. But, some are still eating - just like reptiles. ... when those who eat men compare themselves with those who do not, how ashamed they must be. Probably much more ashamed than the reptiles are before monkeys. (Lu Hsun 15)

$\mathrm{Lu}$ Xun used this metaphor to urge people to change. Through the madman's words, Lu Xun describes the book of Confucian virtue and morality to be all about two words: "eat people." Lu Xun powerfully depicts the repressive reality of traditional China to the readers. No wonder it was considered to be the first and one of the most influential modern works written in vernacular Chinese which marks the beginning of modern Chinese literature. This story was also the first Western-style short story published in New Youth under the pen name Lu Xun. Its satirical attack, which uses the imagery of cannibalism to represent how feudalistic Confucian values destroy Chinese individuals' judgment and value system, aroused heated discussions among the Chinese soon after its publication. The Chinese's "paralysis" (mamu) which resulted in "persecution complex" (Lovell 21) and Lu Xun's depictions of "mad" people in his fiction and prose writing brought awareness of the need for change to the Chinese people. Lu Xun's efforts in appealing for national awareness were understood and appreciated by the educated readers in that tumultuous time.

It was with this background that the whole country became eager to introduce the vernacular Chinese and vernacular writing to the Chinese masses through education. In 1912, the "Middle School Implementation Rule" was issued by the Republic of China's Ministry of Education under the support of Cai Yuanpei. It confirms that the place for people to receive education is at school. The subject of Chinese language was named "Chinese" and the Chinese subject requirements in terms of the educational objectives, teaching contents, and the degree of training were spelled out: "The objectives of learning Chinese are to enable people know how to use the language, express ideas freely, have the basic knowledge of advanced language to cultivate the interests on literature, thus people's wisdom can be inspired" (Bo Jingxi 22).

So this was the opportune moment for the Chinese nation to feel the weight of the national crisis from reading Lu Xun's simple but meaningful literary works. On one hand, the future of the country seemed dim as it faced the reality of western invasion; on the other hand, traditional Chinese society and culture were under a 
process of transformation, which posed great challenges to the intellectuals' ability to adapt to new ideas. Since traditional Confucian education left a strong effect on the Chinese belief that all individuals in a group share a common fate, Chinese intellectuals were inclined to shoulder the responsibility of saving the nation, to speak for those less privileged or illiterate people, and use their writing to influence the rulers. Thus, the May Fourth Movement intellectuals urgently felt the moral responsibility to change the current situation via their knowledge and reputation in the society at the beginning of the 2oth century. To a certain extent, the purpose of writing was for political change-a change that could offer the possibility to end the suffering of the nation. Writing became a kind of symbolic power to help enable social change.

From this perspective, Lu Xun's works were immediately welcomed by the intellectuals of his day after their publication in the 1920s. It might be said that they were evaluated and interpreted by the readers according to the standard of their time. In fact, according to Li Bin, the standards of selecting Chinese textbook essays were based on three points during the period of the Republic of China. Firstly, it ought to have enlightening thoughts to promote Chinese people's spirits. Secondly, it ought to have informative content to enrich people's knowledge. Thirdly, it ought to have complete writing structure to set examples for other scholars. These points might have influenced the fundamental judgment that editors made in choosing Lu Xun's works into the Middle School and High School Chinese textbooks. Thus, some of Lu Xun's articles appeared in different versions of the Middle and High School Chinese textbooks at that time. According to Wang Furen, Lu Xun's works were accepted "with minimum mandatory factors, and thus reflects the different values of Lu Xun's works under different standards" (8) during the 1920 s and 1930 .

To be specific, we can look at the same articles that were included by the main publishing houses from the 1920 s to 1949 (Zhou, Haiying). It may be assumed that the publishing house repeatedly chose some or the same articles to be included in their Chinese textbooks due to the preference of the editor or the responses from the readers. Since those articles included by the different publishing houses were repeatedly selected in other textbooks, it may be said that such selection was a reflection of the whole society's general standard for evaluation of Lu Xun's works. From the statistics, it may be noted that "The Comedy of the Ducks" and "Autumn Night" all appeared in three major textbook publishers, namely: Shanghai Commercial Press, Zhonghua Book Company, and Shanghai World Publishing House's Middle School and High School Chinese textbooks. Other works like "Hometown," "The Kite," "The Wise, the Fool and the Flunkey," "Snow," and "Unfruitful Studious" were also included by two of the above-mentioned publishers at the same time. In general, most of Lu Xun's works included in the Middle School 
and High School Chinese textbooks in the 1920 and the 1930 may be said to be those that represented for them the beauty of vernacular language in writing.

Among them, the articles that most frequently appeared were "The Comedy of the Ducks" (8 times), "Hometown" (8 times), "The Kite" (7 times), "Autumn Night" ( 7 times), "The Wise, the Fool and the Flunkey" (5 times), and "Snow" (4 times). In this regard, John Guillory's statement is supportive when he says that, the function of the first vernacular canons of English literary works was "employed as a means of teaching Standard English" ("Canon" 241). On the other hand, the vernacular Chinese was used to educate the common Chinese public about modern ideas. Following this observation, it can be said that the inclusion of Lu Xun's works in Middle School and High School Chinese textbooks may be regarded "as a means of enhancing prestige" (Guillory, "Canonical" 516) among the public in the period of the Republic of China.

There were more critical essays ( 16 out of 22 ) that appeared in the Central Soviet area, the anti-Japanese base and the liberated areas under the leadership of the Communist Party. Since the guidelines for the Middle School and High School Chinese textbooks were to train their own cultural cadres and encourage people to cooperate with the Agrarian Revolution and the Anti-Japanese War, there were more of Lu Xun's works that spoke of the need to have a fighting spirit and expressed criticism of feudal oppression in the Communist Party-controlled areas. According to Du Xinfang, the Education Department of Shaanxi-Gansu-Ningxia border region published Intermediate Chinese in 1946 and the book contains "Seven Explanations for This Book," which emphasized that the textbook's political value should not be ignored when giving attention to the Chinese language learning. This required that the Chinese teaching syllabus be guided by Marxism, which had a far-reaching influence on the Chinese education in China after the founding of the People's Republic of China.

Take into consideration the invasion from Japan (1937-1945) at the heels of the Kuomintang's cruel suppression. It is easy to understand why the Communist Party paid more attention to the critical essays but not to the prose writing by Lu Xun at that time. Much depended on what they could get from Lu Xun's works; it was mainly about the "function of Lu Xun."

To sum up, the May Fourth intellectuals' changing attitudes towards the novel reflected a utilitarian view (intentionally or not) towards the function of the literature. It can be dated back to the Confucian tradition of regarding literature as a didactic way to encourage the people's obedience to the ruling class. It differs from the Euro-American notions of literature which pay more attention to the people's individuality and liberal spirit. Pedagogical practices during the May Fourth period 
showed the intellectuals' expectations to exert influences upon the masses to accept the new ideas through teaching the vernacular language and vernacular writing to the public. Meanwhile, the use of the vernacular language was historically linked to literature due to the fact that the question of the use of the vernacular language was raised in the context of replacing classical Chinese writing. Thus, the works that could show the beauty of vernacular Chinese and possessed literary value were highly recommended and canonized in the 1920 s and 1930s. This is illustrated by the works by Lu Xun that were included in the Middle School and High School Chinese textbooks during this period.

On the other hand, the Central Soviet area, the anti-Japanese base and the liberated areas under the leadership of the Communist Party-whether in the 1930 or the 1940s-did not follow literary concerns, but rather pragmatic ones. Vernacular literature was viewed as the language of ideological propaganda, the language of education, the tool to mobilize the citizens, and the language to change social reality. From this perspective, the choice of critical essays by Lu Xun rather than his fiction could be interpreted and related to the ideological content of the Chinese textbooks, Lu Xun would eventually be canonized by the Communist Party.

\section{WHY LU XUN WAS DEIFIED BY MAO ZEDONG}

Generally, the positive reception of Lu Xun's works owes as much to his remarkable contribution to the field of literature as to his critical insights about the complex Chinese social reality. Additionally, the role of Chairman Mao in canonizing Lu Xun since the 1930 should not be ignored; for Mao Zedong, politics was in command. On the first anniversary of Lu Xun's death in 1937, Mao Zedong spoke to an assembly at the North Shaanxi Public School in Yan'an and assessed Lu Xun's influence on China as comparable to Confucius: "The value of Lu Xun in China is that he should be regarded as the number one sage of China. Confucius was the sage of the feudal society; Lu Xun is the sage of the New China" (Holm 165). Thus the age of canonization of Lu Xun began.

In order to explain why Lu Xun was given such rich political and ideological colors, it is necessary to explore the reasons why Chairman Mao gave high remarks on $\mathrm{Lu}$ Xun. After discussing Lu Xun's works on revolutionary and proletarian literature, this study asserts that it was because of Lu Xun's elaborations and definitions of revolutionary and proletarian literature that contributed to his full recognition by the Communist Party since the 1930s. A detailed elaboration on this part is crucial because it directly influenced the reception of Lu Xun after 1949. 
As discussed earlier, after the "social" function of fiction was separated from its "pleasure" function in the service of effective propaganda to influence the Chinese masses, the notion of revolution became the main theme of fiction and other literary works since the 1920s. The representations of the "revolution" varied due to its different cultural and historical contexts: It could be about nation-building during the Republic of China, and also about the fight for socialism and communism after the founding of the People's Republic of China. Whatever it may be, it had a close relationship with the dominant power which focused on literature's social concerns and political ideologies.

The origin of revolutionary literature can be traced back to a series of political movements since the 1920s. China witnessed the May Thirtieth Massacre in which the British police killed 13 Shanghai demonstrators on May 30, 1925; the killing by the French marines of 52 demonstrators in Canton on June 23, 1925; the Northern Expedition in 1926-1927; and the Kuomintang's liquidation of the Chinese Communist Party members in 1927. Thus, 1927 saw a wave of criticism against capitalism and brought Marxism into the literary field. At the same time, nationalist fervor began to spread among the Chinese public as well as in the Chinese literary field. The intellectuals engaged in heated debates on the relationship between revolution and literature. Among them was Lu Xun who was skeptical.

The success of the October Revolution in 1917 made the Chinese intellectuals who were trying to find a possible solution to China's problems see possibilities for change in the country. Many Russian literary works were translated into Chinese and the intellectuals began to think about whether China could follow the Soviet way in the creation of a new country or not. In this context, literary works that contained the theme of revolution became popular. Lu Xun's preference for Soviet literature made him knowledgeable about Marxism. According to Lee Ou-fan, it was mainly from the works of Leon Trotsky that Lu Xun formed his ideas on revolutionary literature. In his translation of "Literary Debates in Soviet Russia" (Su'erwenyilunzhan) in 1925, Lu Xun "restated in particular Trotsky's opinion that no revolutionary art had yet appeared in revolutionary Russia but that there were, more importantly, 'revolutionary men"' (Lee 154). In relation to the reality in China, after careful examination, his skepticism on the revolutionary art and literature in the present resulted in his conclusion that only in the future Communist society that real proletarian literature could come into being. In relation to the legality of the proletarian revolution that was originated by Mao Zedong and the Chinese Soviet Republic founded by him in 1931, the abovementioned statement by Lu Xun gave Mao Zedong a sound theoretical support.

Furthermore, when five progressive writers were cruelly killed by the Kuomintang on February 7, 1931, the Leftist Alliance appealed for Lu Xun's help 
to fight against it. Lu Xun's attitude and public censure on the Kuomintang, the Communist Party's opponent, made Mao Zedong regard Lu Xun as the friend that he could rely on. Although some radical leftist writers, like Feng Naichao and Qian Xingcun, criticized the seemingly pessimistic attitudes in Lu Xun's works which they claimed were "opposed to the brightness of revolution" and "could only lead the young to the path of death and could only dig numerous graves for his followers" (Qian 189), T. A. Hsia states that Lu Xun's "beliefs in enlightenment did not really dispel the darkness; but they served as a shield from the dangerous attraction that darkness exercised" (Hsia 161). This coincidentally was consistent with what Mao Zedong practiced during the Chinese Civil War period (1927-1950).

In response to the criticisms from the leftists, Lu Xun replied in his "Literature of the Revolutionary Age" (Gemingshidai de wenxue) that the real agent of revolutionary literature should be the proletariat themselves. He said that only when the whole country's masses were really awakened and the workers and peasants were really participating in literary creations could a country produce a real revolutionary literature (Lu Xun, Complete 422). In this way, the spokesman of the Chinese workers and the peasants-Mao Zedong and the Communist Partyacquired legitimacy.

Feeling the need to use Lu Xun's prestige to help the Communist Party's fight with the Kuomintang, Mao Zedong stated in 1940 that:

$\mathrm{Lu}$ Xun was the greatest and most courageous standard-bearer of this cultural force. The chief commander of China's cultural revolution, he was not only a great man of unyielding integrity, free from all sycophancy... he was also the bravest and most correct, the firmest, the most loyal and the most ardent national hero, a hero without parallel in our history. The road he took was the very road of China's new national culture. (wtd. in Holm 166)

Yuan Shengyong writes about the significance of Mao Zedong's contribution to the canonization of Lu Xun:

He obviously positioned Lu Xun as a Bolshevik outside the party, and used his absolute authority to make Lu Xun leave extensive and far-reaching influences on Chinese ideology and culture, even the political process. However, Mao Zedong gave his evaluation on Lu Xun from the angle of the demand to establish new democracy ideology; it has dense political complexion. As a result, his understanding of Lu Xun's role as a writer and usefulness came from his political perspective. (136) 


\section{HOW LU XUN WAS POSITIONED IN THE MAINSTREAM POLITICAL CULTURE AFTER THE FOUNDING OF THE PEOPLE'S REPUBLIC OF CHINA}

The impact of public opinion can never be ignored as a powerful social force. From the works by Lu Xun, it is known that he held high hopes for literature because he believed in its ability to stir the emotion and spirit of the people, as well as to "move them to action" (Lu Xun, Complete 1: 64). Also, Lu Xun said, "Literature is the bugle of mankind's march towards life's realm of truth, benevolence and beauty, can shake heaven and earth, and its power can touch millions for millennia" (Tsau 451).

Being aware of the important role of literary works in influencing the masses, Mao Zedong delivered "The Speech on Yan'an Art and Literature Forum" in 1942 to regard the works in the literary and artistic field as one of the important arenas in promoting the Chinese Communist Party's ideology and constructing the modern national state's own "imagined community." The purpose was not only to solve specific problems, but also formulate a set of policy and standards in line with the Communist Party of China's ideology in the literary and artistic field (Mao 872).

After the founding of the People' Republic of China in 1949, the new socialist country needed a corresponding language system as well as a new literary system. In this regard, Mao Zedong's "The Speech on Yan'an Art and Literature Forum" became the important reference that guided the selection of Lu Xun's works in the Middle School and High School Chinese textbooks. The uneven road to the establishment of the country's new educational system resulted in the everchanging content of the Middle School and High School Chinese textbooks. In fact, Lu Xun himself once referred to such changes when he said: "Speaking of textbooks, the recent thirty years have witnessed great changes. Ideas about it change every day, principles for today, change the proposals next day" (Lu Xun, Complete 5: 255).

In November 1950, the first set of national Chinese teaching materials which contained Middle School Chinese Textbook (6 volumes) and High School Chinese Textbook (6 volumes) were issued by the State Administration of the Press. Since the educational aim was stated clearly in the Common Programme of the Chinese People's Political Consultative Conference (to “improve people's educational level, eliminate the feudal, bourgeois and fascistic ideology"), it may be said that the main function of the Chinese subject was for political propaganda. Also, Song Yunbin states in his Junior Middle School Chinese Textbook that "all subjects have to fulfill the task of political and ideological education; this is especially true in the Chinese subject. We cannot just rely on some expository articles like manifestos to fulfill the task, a novel, a poem even a historical story can be used to demonstrate some 
ideological contents or political principles... in this way, we can have a great impact on students and guide them" (78).

Later, the Curriculum Research Institute gave the following guidelines to address the problems in compiling Primary and Secondary School textbooks:

The Primary and Secondary School textbooks are the embodiment of the national spirit. The important political point of view it reflects is made by the nation, rather than by the individual, which is widely recognized by all countries in the world... so, compiling the Primary and Secondary School textbooks is different from writing personal academic works. The personal point of view cannot be used and must comply with state laws, regulations and policies. It is through the guidance of abovementioned laws, regulations and policies that the concrete problems can be demonstrated to the public in the textbooks. [...] For example, the evaluations on Three Great Remould, the Anti-rightist Movement, Great Leap Forward Movement and the Cultural Revolution must be based on the relevant documents of the central committee of the Communist Party of China; specifically, the evaluations must agree with "The decisions on certain historical questions of the party since the founding of the People's Republic of China. (689-69o)

Thus, it is clear that teaching materials could be a comprehensive reflection of a country's political culture; in turn, the national political culture plays an important role in guiding the writing of the teaching materials.

To be discussed for comparison in the following sections are the stories that appeared in different historical periods, namely, "The Comedy of the Ducks," "The Kite," and "The True Story of Ah Q."

After examining the changes of Lu Xun's works in the different versions of the Middle School and High School Chinese textbooks, it is interesting to state the following changes in order to illustrate how Lu Xun was used as cultural capital.

\section{THE DISAPPEARANCE OF "THE COMEDY OF THE DUCKS" FROM 1952 ONWARDS}

As the author mentioned in this study, the most popular work by Lu Xun during the Republic of China period was "The Comedy of the Ducks" which was included by the different publishing houses at the same time for many years from the 1920 s to 1949. But in the Chinese textbooks after the founding of the PRC, it did not appear

again in any version of the Middle School and High School Chinese textbooks from 
1952 until now. Why is there such a big difference in the selection? Does it concern the work's literary value or can it be explained by other considerations?

"The Comedy of the Ducks" was written in 1922, based on Lu Xun's friendship with Russian blind poet Eroshenko; in it, the vivid descriptions on Eroshenko's interest toward animals displayed the poet's unique personality. In the last paragraph of the story, Lu Xun expressed his nostalgic feelings about Eroshenko, suggesting why he produced this work. The introduction to the Middle School Fundamental Chinese Textbook (Two) by Shanghai Commercial Press in the 193os states that, "the author cherishes the memory of the days with Eroshenko; his humorous depictions on ducks' eating tadpole represent the author's kind, humorous and lovely personality." To a certain extent, this is merely a short narrative prose without depicting any contradictions, nor any other complication; rather, it is a plain description of everyday life.

So why did "The Comedy of the Ducks" disappear from the 1952 textbook? The answer may lie in Lu Xun's friendship with Eroshenko, whose nationality is Russian. Although it is well known that China followed the Soviet Union's practice to become a socialist country and, indeed, there were some periods that two countries had a close relationship with each other, the reality was far more complicated because of the "smokeless war" between the leaders of the two countries. The "cold war" between China and the Soviet Union can be traced back to the 1930s when the Chinese Communist Party was under the leadership of the Soviet Union. After Mao Zedong refused Stalin's suggestion to merge with the Kuomintang, conflicts between them began to emerge. Stalin was dissatisfied with Mao Zedong's disobedience; in the meantime, Mao Zedong was in defiance of Stalin's domination. Thus "The Comedy of the Ducks" was deleted from the 1952's version of Chinese textbook signalling the start of China's voiceless resistance. The deletion of "The Comedy of the Ducks" has more symbolic meaning signifying the start of the journey for equality between the two countries.

\section{THE EXPLORATIONS ON CHINESE SUBJECT AND CHINESE EDUCATION IN 1956}

The division of the Chinese subject into language education and literature education in 1956 was the first reform in new construction of China's Middle School and High School Chinese textbooks. The objective of literature and Chinese language teaching became fairly explicit and each of them established a rather comprehensive system. In compiling the 1956 and 1957 versions of the Middle School and High School Literature textbook, which were the first and the very last ones in new China, it is notable that the compilers seem to have selected works 
mainly for their literary qualities. Thus, "From Baicao Garden to Three Flavor Study" and "Kung Yiji" were added into the 1956's version, and the critical essay "Astonishment on the Allied Countries' Behavior" was removed.

This version of the Chinese textbooks only lasted for two years and was replaced because "it fails to highlight politics, which is to say, it weakens political education" (Tong Qingbing). So, in 1957, the instrumental function of the Chinese subject was highlighted by the government again; as a result, more critical essays by Lu Xun entered the Chinese textbooks.

\section{THE EFFECTS OF THE SPLIT FROM THE SOVIET UNION}

With the Soviet Union and Chinese government's conflicts in the Great Leap Forward and the Movement of People's Communes in 1959, the Sino-Soviet relations deteriorated and the Soviet Union withdrew all their experts from China in 1960. This caused tremendous financial difficulties for the Chinese government; consequently, the following articles by Lu Xun appeared in the Middle School and High School Chinese textbooks from 1958-1966: "We Will Not Be Deceived Any More," "Astonishment on the Allied Countries' Behavior," "Did Chinese Lose Their Self-confidence?," “On Completely Crush a Defeated Enemy," and "On The Third Kind of People," among others.

Wen Hui News published an editorial under the title of "A Tentative Study on the Objective and Task of Chinese Teaching" on December 16, 1961. It points out that "Chinese is a tool after all, a tool of class struggle, a tool of struggle for production" (Bo Jingxi), so mainly, the teaching goals during 1958-1966 aimed at providing guidance for the Chinese students to see the evil face and reactionary nature of imperialism, realizing the decadence and backwardness of feudalism and the superiority of socialism. The intention was to cultivate hatred of the old society and natural love for the new so as to encourage the youngsters to make a contribution to their motherland in building socialism (Chinese Teaching 1963 49). Thus, the red and white flowers on Xia Yu's tomb in "Medicine" were interpreted as referring to the countless revolutionaries who will not fade away. It was also to be understood that the people would learn lessons from the revolutionary martyrs and open up another bright and successful path for the revolution (Chinese Teaching 1963 12), which was exactly what China did after the setback from the relationship with the Soviet Union. 


\section{LU XUN'S SOLO DURING THE CULTURAL REVOLUTION (1966-1976)}

The study of Lu Xun was monopolized by the Gang of Four during this period. As Yan Jingming says, "[t]he studies on Lu Xun have been seriously affected by the trend of the times. The understanding and evaluations of Lu Xun during the Cultural Revolution can only be made from one perspective, which is the politics" (34). Moreover, the front page of People's Daily on June, 5, 1966, stated that "there are many angles in reading Lu Xun, the number one preference is the political one." It was also said that on the 3oth anniversary of Lu Xun's death in October 1966 in Beijing, Yao Wenyuan arrogantly stated that only several people (including the "Gang of Four" and Si Yige-the author of Lu Xun's Biography) were qualified to commemorate Lu Xun" (Luo Sun).

Lu Xun's "Literature in the Revolutionary Period" describes the three stages of the relationship between revolution and literature: Stage one is the moment when "almost all literature expresses dissatisfaction and sorrow over social realities" before the revolution, stage two is the time that "literature disappears due to the tide of revolution because the country was so busy in waging the revolution so that there is no time to talk about literature," and stage three happens when the revolution has triumphed and only two types of literature exist, one that praises the revolution and another that mourns the decay of the old (Lu Xun, Complete 3: 417-423). It is a stunning work of close observation and really penetrating insight.

In relation to the reality during the Cultural Revolution, the "second stage" happened in ways Lu Xun had described. There was no literature, just the busy revolutionary activities to break away from the past. Although there were more of Lu Xun's articles included in the different versions of the Middle School and High School Chinese textbooks than ever before, their inclusion meant that Lu Xun was, indeed, used as the medium for the government's mainstream ideology. Even the teaching of Lu Xun's works was mainly focused on the demand of the times to interpret and confirm the political structure and the prevailing policy in real life but not on his artistic and aesthetic values or his distinctive writing skills. $\mathrm{Lu}$ Xun was aligned or made to align with the political struggle and propaganda demands to convince the masses to follow the government's policy and comply with it with the strongest conviction. For example, when Mao Zedong criticized Lin Biao and Kuomintang's similarity in honoring Confucianism in July 1973, Lu Xun's "Confucius in Modern China" appeared in Gangsu High School Chinese Textbook immediately. In this context, when Mao Zedong criticized Song Jiang's capitulationism in 1975, "The Changes of Hooligan" was included in Liaoning Middle School and High School Chinese Textbook. Similarly, the interpretations of "Kong Yiji" could reveal the failure and shortcomings of bourgeois education, 
while "Hometown" could show the darkness of feudal China, and "The New-Year Sacrifice" could prove the correctness of the Cultural Revolution.

Lu Xun could never have imagined that what he described as political repression on artistic expression (Lu Xun, Complete 7: 113) would ironically happen to him. Other intellectuals who experienced the repression were degraded as "stinking old ninth" (the Chinese idiom for the lowest class in the Chinese society) and were forced to do manual labor during the Cultural Revolution because the government insisted that "the literati are the ones who incite social disturbance" (Lu Xun, Complete 7: 118). In the case of Lu Xun, his literary productions were misread and interpreted arbitrarily in accordance with the nation's demands to prove the correctness of the state policy and ideology, even the validity of the Cultural Revolution.

From the perspective of the Communist Party, things were different. Wang Ban states in his The Sublime Figure of History: Aesthetics and Politics in TwentiethCentury China that politics can be productive if it is able to transform itself into art because it "embodies the abstract telos of history and inspires the people with daunting and awe-inspiring figures" (192). In the context of the predicament that China was experiencing from 1949 to 1976, what Mao Zedong did in the canonization of Lu Xun may be said to be understandable, if opportunistic.

Lu Xun's works were included in the Middle School and High School Chinese textbooks during these 17 years, so the design of the curriculum must have left extremely far-reaching influences on several generations who were brought up after the founding of the People's Republic of China. The reason for the influence is that only after the founding of People's Republic of China did the mass public have the chance to receive formal education, which enabled them to be acquainted with $\mathrm{Lu}$ Xun and his works more closely. Moreover, the Chinese language teaching had been so heavily affected by the domestic political environment which assumed that the teaching of Lu Xun's works was meant to advocate the proletarian ideology and eliminate the bourgeois ideology.

\section{OPEN-DOOR POLICY AND THE INFLUENCE OF THE MARKET ECONOMY}

With the collapse of the Gang of Four, which declared the end of the Cultural Revolution in October 1976, Deng Xiaoping resumed power to lead the country in 1977. Reflecting on the mistakes in the past and the experiences from the West, he realized the importance of developing the talent and abilities of the citizens. His views on art and politics contrasted with his predecessors. He said, "We should 
stop using the slogan such as 'Art should serve politics' because it easily becomes an excuse for the wanton interference upon literature and art. Our long term practices have proved that it brought more harm than good for literary and artistic development" (220).

So, in September 1977, the Chinese Ministry of Education organized scholars and educators to re-edit Primary and Middle School textbooks. It corrected the past guidelines which focused more on politics and designed the new guidelines for the new Chinese textbook compilation. It stated that the starting point and the target of Chinese subject is to facilitate the students' holistic development. Toward this end, the textbooks should provide the basic and broad knowledge which would help to cultivate the students' language proficiency and academic attainments. Additionally, it should develop the spirit of innovation and creativity so that the students could learn and practice Chinese autonomously. Thus, a new page in the history of Chinese education in China was turned. More attention was given to humanistic education since the implementation of the reform and opening-up policy.

Apart from some slight changes, like the removal of "The Kite" and "Snow" after the 1981's Middle School Chinese version, Lu Xun's works that were included in the three versions of the Middle School Chinese textbooks (1978, 1987, and 1992) were almost the same. Except for the two critical essays, "Astonishment on the Allied Countries' Behavior" and "On the Fall of The Leifeng Pagoda" among the 11 articles, the rest have been said to have "well-written content, healthy and positive, can show the beauty of language and suitable for teaching" (Middle 5).

Furthermore, there were comparatively big changes in the three versions of the High School Chinese Textbooks (1980, 1987 and 1992). “A Madman's Diary” was not included in any version of High School Chinese Textbooks after 1982. Also, it is worth noting that "Fan Ainong," "Grabbism," and "Autobiography of Lu Xun" were included for the first time in the People's Education Press's Chinese Middle School and High School textbooks during this period. "On the Postponement of Fair Play" also first appeared in the 1987's version of High School Chinese.

In "Grabbism," Lu Xun argues that since the Chinese have lost so many things (willingly or unwillingly) and also been forced to accept so many unequal treaties (since the First Opium War), it is now the time to employ the theory of "Grabbism" to treat foreign things. Lu Xun said, "[w]e need to seize it, and then we need to [decide] either to use it, store it or destroy it. In that way, the old master is the new master and the house will become a new house" (Lu Xun 2002, 557). To a certain extent, it coincides with the Chinese government's attitudes toward the outside world after the implementation of the open-door policy. Like the famous saying 
by Deng Xiaoping, “It doesn't matter whether the cat is black or white, as long as it catches mice." Intended to enhance the nation's comprehensive competitiveness in the world, on the one hand, the government focused firmly on economic reform and marketization; on the other hand, China tried her best to absorb all kinds of knowledge and ideas from other countries. The new era's "grabbism" is about choosing those that are most beneficial to China, while removing those that are not.

Later, the popular culture flourished in the 1990s which made Chinese intellectuals start to take the loss of the humanist spirit seriously, in the wake of industrialization and commercialization. The concerns on the humanist spirit prompted heated discussions during China's increasing involvement in international politics and the global economy. Thus, after releasing the policy of the nine-year compulsory education (Primary and Middle School education) in 1986, the Chinese government issued the following: the curriculum reform of basic education as well as the Decision on the Deepening of Educational Reform and the Full Promotion of Quality-Oriented Education in 1999, the Basic Education Curriculum Reform Outline (trial) promulgated in 2001.

In 2000, the State Council issued Action Plan for Revitalizing Education which called on the educational community to "implement cross-century quality education project for the promotion of quality education, general citizen's quality and national innovative capacity." In this action plan, "the curriculum and evaluation system shall be reformed to constitute the modern basic education curriculum framework and standards, educational content and teaching methods and the new evaluation system and teacher training in early 20oo." Finally, it stipulated that the "basic education curriculum system shall be circulated around China through a 10-year curriculum experiment" (Zhou Nanzhao and Zhu Muju 22). The new curriculum reform aimed to construct the curriculum of basic education that accorded with the demand of quality-oriented education in the 21st century, which was inspired by the reform experience of advanced countries and complied with the trend taking place in the world. The object was explicit in the curriculum reform of the Middle School and High School Chinese education which was to reach the unification of humanity and to serve pragmatic functions.

It is not easy to explain why there were less and less of Lu Xun's works in the Middle School and High School Chinese textbooks under the above-mentioned policies because humanism is never lacking from Lu Xun's works such as "The True Story of Ah Q" and "The Kite." Thus, the explanation may be drawn from the question of what the Chinese government might want to get from Lu Xun in the new era. The answer may be discovered in the understanding of the relationship between literature and politics. Although both of them fight for dominance in the process of representing the imagined worlds, the relationship is also symbiotic. But 
in China, politics has long dominated literary discourse. The use or uses of Lu Xun's works may be illustrative. Therefore, the symbiosis between literature and politics is marked by a tension resulting in a negotiated space wherein the canonicity of $\mathrm{Lu}$ Xun in the history of Chinese literature lies.

It must be pointed out, however, that for all the claims of the government to humanize the curriculum, it remains questionable on the grounds that factually the works of Lu Xun represented in the Chinese textbooks have been reduced since 200o. Theoretically, the apparent move towards humanism has been geared toward assuring the continuous development of the country in view of the globalization to which every citizen could contribute. In practice, however, the works by Lu Xun that could have helped develop critical citizenship have been excluded from the new textbook, like "The True Story of Ah Q" and "The Kite."

\subsection{The disappearance of "The True Story of Ah Q" in 2007}

“The True Story of Ah Q," Lu Xun's best-known fictional creation of the Chinese everyman, narrates a thoroughly delicately woven story about the weaknesses of the Chinese national character. Typically, Lu Xun depicts through the character Ah $\mathrm{Q}$ to show people's desperation, ignorance, paralysis (mamu), submission to humiliation, and lack of sympathy under the long experience of feudal autocratic enslavement in China.

A small village, Weizhuang, witnesses the experience of a nameless ignorant farm laborer, an everyman Ah Q, of all kinds of humiliations and defeats. Ironically, Ah Q does not feel sorrow about his miserable life but sublimates all his failures in the imagination of psychological victories and thinking that he was humiliated by his "son" and such. What is worse, when confronted with the less fortunate and the weak, Ah Q becomes a thorough bully, but if those people are above him in rank, strength, or power, he cowers and gets ready for a beating. His personality is a strange combination of arrogance and self-contempt because, on the one hand, he views himself as superior to nearly everyone; on the other hand, he is eager to get people's attention even at the cost of his dignity. Thus, his initial negative response to the revolution changes when he realizes the fear of his fellow villagers towards it; and so he lies to them by claiming that he belongs to the revolutionary army. Unfortunately, instead of gaining the fame and fortune he longs for, he is executed for he is blamed for the chaos of a robbery.

Ah Q's characterization seems vague and ambiguous. First, Ah Q is homeless, friendless, and even nameless. Although the author uses Ah Q to name him, the 
name is foreign to the Chinese and is not accepted by them. Thus, Ah Q's lack of identity and the author's intention to imply the loss of self in the character were established successfully. Second, Ah Q is unable to understand the reasons for his miserable situation; in fact, he does not realize that his life is miserable. He is overjoyed by a remark which was given by the landlord, and lives in the nature of an animal: When he feels hungry, he will look for food; and when he feels cold, he will look for shelter. Consequently, in order to escape from the humiliation and disillusionment of the reality, Ah Q can only indulge in his dreams and seek comfort from his fantasies. In this way, he remains unawakened. This alludes to the unawakened souls due to the thousands of years of feudal enslavement in China. In the story, the shortcomings of the Chinese national character as mirrored in Ah $\mathrm{Q}$ and his fellow villagers are vividly depicted by Lu Xun. Finally, when Ah Q takes great pains in signing his name on his death verdict, he draws a zero-like circle which implies his nothingness in this world.

“The True Story of Ah Q" was written in 1921 because of Lu Xun's concern with the fate of the Chinese nation and his determination to be its spiritual physician. Depicting a typical double-sidedness-being tormented and being the tormentorAh Q and his story attracted the Chinese's attention for social reform and selfreflection for generations. Such explanations as "there are distinct differences between the social settings of Lu Xun's works and that in the present-day China" do not persuasively account for the disappearance of "The True Story of Ah Q" from Middle School and High School Chinese textbooks.

"If you can see, look. If you can look, observe" (Saramago 1). Unfortunately, most modern people lacked this kind of ability. So Lu Xun created a story to help people know how to "see," in the hope that, their consciousness of self could be re-awakened. The more critical the attitude towards people's self-image, the more hope there is to reconstruct the national spirit.

But the point lies in the need to develop critical thinking. Many scholars agree that Lu Xun's contribution to the country lies not only in literature, but also in his reflections on the Chinese society and his daring spirit to question the orthodoxies and authorities. His works are excellent teaching materials to cultivate students' critical thinking.

The dramatic spread of marketization opened up spaces and opportunities as well as problems for the Chinese, such as corruption and misuse of authority, materialism, consumerism, individualism, among others. Therefore, questions about the legitimacy of economic reform were not welcomed by the Party-state. In the name of developing a modern culture, the Party's ideology has succeeded in standardizing the citizens' identity. The party believes that stability is the priority 
so it is easy to understand why the central government does not show enough enthusiasm in encouraging the youth today to form the habit of critical thinking in spite of the policy, in the name of producing quality education.

The late 1990 s also saw the rise of Chinese nationalism, which appealed to the need for a powerful state to keep China strong and united. Triumphs like joining the World Trade Organization in 2001, winning the bid for 2008 Olympics in 2003, and playing an active role in numerous international affairs have increased the country's confidence to be internationalized more than ever before. The state's reasoning might be this: Since it is the time to change the world's impression towards China, the image of Ah Q should no longer be associated with a new globally-competitive China.

On the contrary, it may be argued that it is still significant to reread "The True Story of Ah Q" in today's China in order to distance oneself critically from the fastpaced society which has made people rush forward aimlessly and purposelessly.

\subsection{The Kite that flies away}

After the removal of "The True Story of Ah Q" in 2007, the latest version of seventh-grade Middle School Chinese textbook saw the disappearance of "The Kite" in 2013 as well, triggering another outcry among the Chinese. Numerous people posted their comments online and more than 85 percent of respondents disagreed with the removal of the works by Lu Xun.

In response to the established fact that "The Kite" was dropped from seventhgrade Middle School Chinese textbook in 2013, the People's Education Press gave the following clarification on September 6, 2013:

There are comments from the teachers that although this article deals with the affections between brothers, and the introspection of the author, there are some paragraphs whose contexts are beyond the comprehension of the students at this age, affecting the students' grasp of the theme. Therefore, we follow the teacher's opinion and students' cognitive rules to replace it; otherwise, it will cause difficulties in teaching. ${ }^{3}$

People who have read "The Kite" may be baffled by the statement from the People's Education Press. How can such well-organized and beautifully written prose not be an age-appropriate material for teenagers? Also, it seems ridiculous to say that the students should not be reading such "deep and abstruse work." 
"The Kite" talks about the narrator's regret for destroying his little brother's toy kite. When the narrator tries to ask for the forgiveness of his little brother to assuage his own guilt many years later, the latter's answer was, "Did that really happen?" instead of giving him forgiveness. Thus, the heart continues to hang heavily. From the descriptions of this small incident, the reader is filled with regret and self-doubt. As Paul B. Foster says:

It tells a personal story of the negative psychological consequences of forgetting... provides insight into another dimension of the "ability to forget": even after "enlightenment" the victimizer will never be able to unburden himself of the guilt of past deeds (since the incident was forgotten by the victim), unless he himself uses the characteristic of forgetfulness, which would ironically be to lapse into unenlightened mentality. Enlightenment entails the development of a historical memory ... it also demands the unwillingness to lapse back into forgetfulness, even if the consequence requires living with the truth of his evil deed. (148)

Thus, "[t] he thing was completely forgotten, with no hard feelings. In that case, what forgiveness could there be? Without hard feelings, forgiveness is a lie. What hope is there for me now? My heart will always be heavy" (Foster 148).

Therefore, the ability to remember was highlighted, which was related by some netizens to the issues of historical memory in China today. Also, the Chinese authority's intentions to promote ideological conformity and instil patriotism among the youth were discussed. It may be said that, like "The True Story of Ah Q," the value of "The Kite" lies in its reflective and self-critical spirit. Lu Xun's despair was due to the conflict between the traditional and modern culture, the paradox between self-fulfillment and the hope for the positive communal environment.

The split personality of “Ah Q" embodies Lu Xun's desire to criticize social reality, awaken the Chinese from sleep in order to change it. Thus, there might be hope to create a stronger China, a new and better society for every Chinese to live in, and to forge a new national identity for them. "The True Story of Ah Q" and "The Kite" could clearly be effective tools for the discovery of the real world. Similarly, Lu Xun's other works continue to be relevant by offering critiques on current social and political issues.

The negative descriptions on the Chinese character and tragic endings in his works suggest, in Rey Chow's words, Lu Xun's refusal “to use his own educated tools to create false senses of optimism for oppressed classed... to deproblematize their suffering within a class-generated ideology of revolution" (112). 
Recently, there seems to be a trend to restore the ancient ways. In fact, traditional Confucianism and its classics have become more popular in the society today. This phenomenon may be regarded as the Chinese intellectuals' temporary solution to the confusions and frustrations due to the loss of the humanist spirit in the new period of globalization. However, the uncritical attitude toward the local tradition on modern ideas has led to irrational decisions in the search for the right "position" for the Chinese. The reason is the inability to deal with the past critically due to a series of Party-state social movements like anti-Confucianism during the Cultural Revolution.

This is not to blame the local tradition or the study of Confucian ideas. The point here is that the deletion revealed the ambivalence of the central government's attitudes towards Confucianism associated with pre-revolutionary China, and Lu Xun became the sacrificial lamb in the dominant power play. The canon can be referred to as the canon not only because of the presence of literary features and the use of excellent writing techniques, but canonicity also lies in the collective relevance of literature. It is the collective relevance of the canon that renders the canonicity meaningful rather than any arbitrary considerations like the claim for outdatedness. Otherwise, as Lu Xun says in "The Divergent Roads of Art and Politics": "I have always felt that art and politics are often in mutual conflict. At first, art and revolution were not opposed to each other; they shared the same discontent with the status quo. Yet politics attempts to maintain the status quo, so it naturally stands in the opposite direction of art, which is discontented with reality" (qtd. in Liu Kang 58).

In short, Lu Xun's works are in a sense performative in that they were constructed to produce the "effect of $\mathrm{Lu}$ Xun" for teenagers to perform certain functions and produce effects in society. This Lu Xun was used to transmit intentions and preferences; therefore, the ways of teaching and reading also become ways of being. The ups-and-downs of Lu Xun's works in the past century were mainly about the practice of power play of dominant forces and institutions in society. By installing Lu Xun's authority as legitimate and persuasive, Lu Xun became a kind of cultural capital that can be passed on. But from an appreciation of the modern aesthetics and use of the vernacular language by the Chinese readers to his use by the state's propaganda machinery, to the changes in the representations of his works in Chinese textbooks, Lu Xun seemed to have occupied an unstable space whose hybridity shuttled between the aesthetic and the political throughout modern Chinese history. 


\section{Notes}

1. Liu, Alice Xin. "Julia Lovell on translating Lu Xun's complete fiction: 'His is an angry, searing vision of China." 11 Nov. 2009 posted on http://www.danwei.org/ translation/julia_lovell_complete_lu_xun_f.php

2. http://article.yeeyan.org/compare/162464

3. http://www.pep.com.cn/rjs/jqgg/201309/t20130906_1164895.html 


\section{WORKS CITED}

Benton, Michael. "Canons Ancient and Modern: The Texts We Teach." Educational Review, vol. 52, no. 3, 200o, pp. 269-277.

Bo, Jingxi. The Acceptance Process of Lu Xun's Works in Middle School. Dissertation of Northeast Normal University. 2007.

Bourdieu, Pierre. The Field of Cultural Production: Essays on Arts and Literature. Columbia UP, 1993.

Bressler, Charles E. Literary Criticism: An Introduction to Theory and Practice. $4^{\text {th }} \mathrm{Ed}$, Pearson Education, 2007.

Chinese Teaching Reference of the Ten-Year Secondary School. Volume 1, People's Education Press, 1963.

Chow, Eileen Cheng-yin, and Carlos Rojas, editors. Rethinking Chinese Popular Culture: Cannibalizations of the Canon. 2008.

Deng Xiaoping. Deng Xiaoping wenxuan: 1975-1982 (Selected Works of Deng Xiaopin [19751982]). People's Publishing House, 1991.

Foster, Paul B. Ah Q Archaeology: Lu Xun, Ah Q, Ah Q Progeny and the National Character Discourse in Twentieth Century China. Lexington Books, 2006.

Gilbert, Sandra M., and Susan Gubar. Masterpiece Theater: An Academic Melodrama. Rutgers UP, 1995.

Greenbaum, Vicky. "Expanding the Canon: Shaping Inclusive Reading Lists." English Journal, vol. 84, 1994, pp. 36-39.

Guillory, John. "Canon." Critical Terms for Literary Study. Edited by Frank Lentricchia and Thomas McLaughlin. U of Chicago P, 1990.

-.. Cultural Capital: The Problem of Literary Canon Formation. U of Chicago P, 1993.

--. "Canonical and Non-canonical: A Critique of the Current Debate." English Literary History, vol. 54, no. 3, 1987, pp. 483-527.

Holm, David. "Lu Xun in the Period 1936-1949: The Making of a Chinese Gorki." Lu Xun and His Legacy, edited by Leo Ou-fan Lee, U of California P, 1985, pp. 153-179.

Hsia, Chih-tsing. A History of Modern Chinese Fiction, 1917-1957. Yale UP, 1961.

Hunter, James Davison. Culture Wars: The Struggle to Define America. Basic Books, 1991.

Jameson, Fredric. The Political Unconscious: Narrative as a Socially Symbolic Act. Cornell UP, 1981.

Lee, Leo Ou-fan. The Romantic Generation of Modern Chinese Writers. Harvard UP, 1973.

Li, Lianjun. "On Changes and New Characteristics of Modern Fiction."Journal of Sichuan Normal University (Social Science Edition), vol. 37, no. 5, 2010, pp. 86-93.

Liang, Qichao. "Lun xiaoshuo yu qunzhi zhi guanxi" (Talking about the Relationship between Fiction and Mass Government). Theoretical Materials of Twentieth-Century Chinese Fiction (Volume One 1897-1916), edited by Chen Pingyuan and Xia Xiaohong, Beijing University, 1989, pp.50-54 .

Liu Kang. Aesthetics and Marxism: Chinese Aesthetics Marxists and Their Western Contemporaries. Duke UP, 2000. 
Liu, XiangAn. "Wenxue jiaoyu yu wenxuejingdian" (Literary Education and Literary Canon). Journal of Suzhou University, vol. 5, 2011, pp. 21-24.

Lovell, Julia. "Diary of a Madman." Translated by Lu Xun. The Real Story of Ah-Q and Other Tales of China: The Complete Fiction of Lu Xun, Penguin Classics, 2009, pp. 48-62.

Lu Hsun. Selected Stories. Norton, 1960.

Lu Xun. Complete Works of Lu Xun. Volume 1. Renmin wenxue chuban she, 1981.

-.. Complete Works of Lu Xun. Volume 3. People's Literature Publishing House, 1981.

--. Lu Xun wen cui. 1st edition. Wen hua yi shu chu ban she, 2002.

Luo Sun. Guanyu luxun yanjiu zhong de jige we ti (Some Issues on the Study of Lu Xun). Lu Xun Study. Vol.1. 1983.

Luo Xinfang. "Zhongxue yuwen jiaoxue dagang bainian (Middle School Chinese Teaching Syllabus in One Hundred Years)". Tianzhong xuekan (Journal of Tianzhong, vol. 3, 2002, pp.115-117 .

Mao Zedong. Zai Yan'an wenyi zuotanhui shang de jianghua (The Speech on Yan'an Art and Literature Forum). Mao Zedong Anthology. Volume 3. People's Publishing House, 1991.

Middle School Chinese Teaching Syllabus in Ten-years Fulltime School System. People's Education Press, 1980.

Qian Xingcun. "The Dead Age of Ah Q (Siqu le de Ah Q shidai)." Selected Materials from the Debates on Revolutionary Literature (Geming wenxue zhenglun ziliao xuanbian), Beijing renmin wenxue chuban she, 1981, pp.182-195 .

Saramago, Jose. Blindness. The Harvill Press, 1997.

Song Yunbin and Zhu Wenshu. Chuji zhongxue yuwen keben (Junior Middle School Chinese Textbook). People's Education Press, 1950.

Tong Qingbing. Buyao cuoguo lishi jiyu (Do Not Miss the Historic Opportunity). Beijing Literature. Volume 7. 1998.

Tsau, Shu-ying. "They Learn in Suffering What They Teach in Song." Symbols of Anguish: In Search of Melancholy in China. Edited by Wolfgang Kubin, Peter Lang, 2001, pp. 441-468.

Wang Ban. The Sublime Figure of History: Aesthetics and Politics in Twentieth-Century China. Stanford UP, 1997.

Wang, Furen. Zhongguo luxun yanjiu de lishi yu xianzhuang (The History and Present Situation of Lu Xun Study in China). Fujian Education Press, 2006.

$\mathrm{Xu}$, Shoushang. "Wo suo renshi de Lu Xun" (The Lu Xun I know). Modern Chinese Literature in the May Fourth Era. Edited by Merle Goldman, Harvard UP, 1977.

Yang, Hsien-yi and Gladys Yang, translators. Lu Xun [Zhou Shuren]. Selected Stories of Lu Hsun 196o. Foreign Language Press, 1978.

Yuan Shengyong. Lu Xun: From Vintga to Enlighten (Luxun: cong fugu zouxiang qimeng). Sanlian Bookstore, 2006.

Yan Jingming. The Cultural Horizon of Lu Xun (Luxun de wenhua shiye). Kunlun Press, 2001.

Yin, Bing. “Lun Xiaoshuo Yu Qunzhi Zhi Guanxi.” Xin Xiaoshuo 1, 1902, pp. 33. 
Zhou, Haiying and Zhou, Lingfei. "What are Lu Xun's works in Primary, Middle and High School Chinese Textbooks?” Digest of Chinese and Foreign Books 1, 2012, pp. 62-70.

Zhou Nanzhao and Zhu Muju. Educational Reform and Curriculum Change in China: A Comparative Case Study. 2006. 